\title{
Ecological Biogeography of Southern Ocean Islands: Species-Area Relationships, Human Impacts, and Conservation
}

\author{
S. L. Chown, ${ }^{1, \star}$ N. J. M. Gremmen, ${ }^{2, \dagger}$ and K. J. Gaston ${ }^{3,}$
}

1. Department of Zoology and Entomology, University of Pretoria, Pretoria 0002, South Africa;

2. Bureau Data-Analyse Ecologie, Dwarsdrift 24, 7981 AP Diever, The Netherlands;

3. Department of Animal and Plant Sciences, University of Sheffield, Sheffield, S10 2TN, United Kingdom

Submitted December 9, 1997; Accepted April 20, 1998

Abstract: Previous studies have concluded that southern ocean islands are anomalous because past glacial extent and current temperature apparently explain most variance in their species richness. Here, the relationships between physical variables and species richness of vascular plants, insects, land and seabirds, and mammals were reexamined for these islands. Indigenous and introduced species were distinguished, and relationships between the latter and human occupancy variables were investigated. Most variance in indigenous species richness was explained by combinations of area and temperature (56\%) - vascular plants; distance (nearest continent) and vascular plant species richness (75\%) —insects; area and chlorophyll concentration (65\%) - seabirds; and indigenous insect species richness and age (73\%)-land birds. Indigenous insects and plants, along with distance (closest continent), explained most variance $(70 \%)$ in introduced land bird species richness. A combination of area and temperature explained most variance in species richness of introduced vascular plants (73\%), insects (69\%), and mammals (69\%). However, there was a strong relationship between area and number of human occupants. This suggested that larger islands attract more human occupants, increasing the risk of propagule transfer, while temperature increases the chance of propagule establishment. Consequently, human activities on these islands should be regulated more tightly.

Keywords: species-area relationships, terrestrial biotas, southern ocean.

\footnotetext{
*E-mail: stevec@scientia.up.ac.za.

† E-mail: gremmen@wxs.nl.

\$ E-mail: k.j.gaston@sheffield.ac.uk.

Am. Nat. 1998. Vol. 152, pp. 562-575. (C) 1998 by The University of Chicago. 0003-0147/98/5204-0005\$03.00. All rights reserved.
}

The islands of the southern ocean are of considerable biological and conservation importance. They form the nesting grounds of a significant portion of the world's procellariiform seabirds (Chown et al. 1998), house a considerable variety of endemic species (Holdgate 1965; Gressitt 1970; Greene and Walton 1975; Gremmen 1981; Prince and Croxall 1983; Woods 1988; Evenhuis 1989; Greenslade 1990; Turbott 1990; Patrick 1994; Kuschel and Chown 1995; Morrone and Anderson 1995), and because of the paucity of land in this region, provide the only examples of mid- to high-latitude southern terrestrial biomes.

Furthermore, unlike many other islands, the direct impact of humans on the southern ocean islands has generally been slight (Smith and Lewis Smith 1987; Cooper and Ryan 1994; Young 1995), and their biotas are remarkably intact (see Milberg and Tyrberg 1993 and Steadman 1995 for discussion of island extinctions). Nonetheless, humans have had indirect impacts on many of these islands as a consequence of the introduction of invasive plants and of synanthropic mammals (Gremmen 1981; Bonner 1984; Leader-Williams 1988; Chapuis et al. 1994; Young 1995). However, a sufficient number of islands either has remained free of invasive plants and feral animals (e.g., Smith and Lewis Smith 1987; Chapuis et al. 1994; Cooper and Ryan 1994) and/or has had their feral animals eradicated or controlled (Dingwall 1995), to warrant their consideration as pristine islands.

As a consequence, these islands are now forming the focus of an intense debate. On the one hand, there are considerable grounds for their conservation, as the preceding observations indicate, while on the other hand, the demand for tourism to these islands, and, therefore, the potential for new alien introductions (which have been shown to have significant impacts; Bonner 1984; Chown and Smith 1993; Ernsting et al. 1995; Gremmen 1997), is increasing rapidly (Dingwall 1995).

Among island biotas, those of the southern ocean are also thought to be anomalous. Although a variety of sea- 
bird species nest on these islands, land bird (and mammal) faunas tend to be depauperate (Derenne et al. 1976; Prince and Croxall 1983; Weimerskirch et al. 1989; Selkirk et al. 1990; but see Woods 1988; Turbott 1990). Likewise, vascular floras and insect faunas are relatively species poor, with Gressitt (1970) referring to the latter as highly disharmonic: many generally common insect orders are underrepresented or entirely absent from most of the islands. Among those insects that are present, there is an exceptionally high incidence of flightlessness (Roff 1990). Gressitt (1970) argued that the considerable geographic isolation and low temperatures of these islands, and in many cases their extensive Neogene glaciation, were the causes of these patterns.

Empirical analyses appear to bear out these observations. Abbott (1974) found that area was of minor importance in explaining plant, insect, and land bird species richness on the southern ocean islands. Rather, mean temperature of the coldest month accounted for most variation in plant species richness, and the plant species richness accounted for most variation in insect and land bird species richness. Using data for smaller groups of southern islands, an earlier study (Chown 1990) came to the conclusion that past glaciations rather than area were of major significance in determining insect species richness (see also Kuschel 1964, 1971; Chown 1994), while Williams (1982) found that plant species richness was an important predictor of insect (Lepidoptera, Coleoptera, and Diptera) richness but that island area was less important. Burger (1985) and Kuschel (1991) reached similar conclusions for most of the southern ocean islands. Thus, both empirical analyses and evidence from systematic and biogeographic studies suggest that southern ocean islands are perhaps unlike most others (see MacArthur and Wilson 1967; Rosenzweig 1995) in that area has much less of an influence on species richness than do past glacial extent, isolation, and low temperature.

However, the validity of this conclusion remains questionable. In this article, we reassess the relationships between physical and biological variables and the species richness of the biotas of the southern ocean islands and, because of the current debate on their usage, the impacts humans have had on them. Our aims are twofold. First, we reexamine previous conclusions regarding speciesarea relationships and the influence of isolation, low temperature, and past glaciations on the biotas to determine whether the islands really are "anomalous." We suspect that many of the conclusions of previous qualitative and empirical analyses are likely to be in error for the following reasons. Abbott (1974; see also Williams 1982; Kuschel 1991) used total area of the islands, mean winter temperature, and a selected group of insect species in his analyses. Many of the islands are covered by glaciers, thus excluding much of their area as relevant to such analyses (e.g., $80 \%-85 \%$ of Heard and South Georgia Islands are currently glaciated). A large proportion of the islands have also not had meteorological stations on them, thus making necessary the questionable extrapolation of mean winter temperatures from nearby stations. With regard to the vascular plants, insects, and bird species, none of the previous workers drew a clear distinction between introduced and indigenous species, even though the factors accounting for the richness of these groups are likely to be rather different. In addition, the Collembola faunas of many of the islands (which were included in the insect faunal lists in some previous analyses) are not well known (e.g., those of Tristan da Cunha, Marion Island, and the Falkland Islands; P. Greenslade, personal communication), making assessments of relative species richness rather problematic. Second, we examine the relative impact of human occupancy of these islands on the species richness of the introduced vascular plants, insects, birds, and mammals.

\section{Methods}

Our rationale for including the particular islands in this analysis (table 1) was strictly biogeographic. They all either share a number of species (Johns 1974) or genera (Holdgate 1960, 1965; Wace and Holdgate 1976; Robinson 1984; Chown 1990) or have sister taxa occurring on them (Brundin 1987; Kuschel and Chown 1995), and overall there is considerable precedence for considering these islands a single biogeographic unit (Watson et al. 1971; Barrat and Mougin 1974; Chown 1997; Chown and Gremmen, unpublished manuscript).

The islands were considered on an island-by-island basis wherever possible. Thus the five constituent main islands of the Crozet archipelago were examined separately, as were East and West Falkland. For some archipelagos, this was not possible because the data for separate islands are too scant. The physical variables, total area, ice-free area, distance to the closest continent (excluding Antarctica), maximum altitude, minimum age of surface rocks (in million years, myr), and extent of glaciers at the Neogene maxima for each of the islands (table 1) were obtained mostly from the primary literature (e.g., Wace and Holdgate 1976; Clark and Dingwall 1985; Hall 1990; LeMasurier and Thomson 1990; Selkirk et al. 1990; Higham 1991; Cooper and Ryan 1994; Dingwall 1995; Young 1995). Ice-free area was calculated as total surface area minus the area currently covered by glaciers (usually given as a percentage of total area), and throughout this article, area thus refers to ice-free area, unless otherwise stated. Many of these islands have not had meteorologi- 


\section{The American Naturalist}

Table 1: Physical variables for each island

\begin{tabular}{|c|c|c|c|c|c|c|c|c|c|c|c|}
\hline Island & \multicolumn{2}{|c|}{$\begin{array}{c}\text { Position } \\
\text { (decimal degrees) }\end{array}$} & \multirow{2}{*}{$\begin{array}{c}\begin{array}{c}\text { Area } \\
\left(\mathrm{km}^{2}\right)\end{array} \\
3,500\end{array}$} & \multirow{2}{*}{$\begin{array}{c}\begin{array}{c}I F A \\
\left(\mathrm{~km}^{2}\right)\end{array} \\
3,500\end{array}$} & \multirow{2}{*}{$\begin{array}{c}\begin{array}{c}\text { Altitude } \\
(m)\end{array} \\
701\end{array}$} & $\begin{array}{c}\text { Minimum } \\
\text { age } \\
\text { (myr) }\end{array}$ & $\begin{array}{l}\text { Distance } \\
(\mathrm{km})\end{array}$ & \multirow{2}{*}{$\begin{array}{l}\begin{array}{l}S S T \\
\left({ }^{\circ} \mathrm{C}\right)\end{array} \\
7.67\end{array}$} & \multirow{2}{*}{$\begin{array}{c}\begin{array}{c}\text { Glaciation } \\
\text { (rank) }\end{array} \\
3\end{array}$} & \multirow{2}{*}{$\frac{\text { Date }}{1833}$} & \multirow{2}{*}{$\frac{\text { Occupants }}{101}$} \\
\hline West Falkland & $51.5 \mathrm{~S}$ & $60.5 \mathrm{~W}$ & & & & 2,500 & 530 & & & & \\
\hline East Falkland & $51.5 \mathrm{~S}$ & $58.5 \mathrm{~W}$ & 5,000 & 5,000 & 705 & 2,500 & 550 & 7.29 & 2 & 1833 & 2,701 \\
\hline South Georgia & $54.25 \mathrm{~S}$ & $37.0 \mathrm{~W}$ & 3,755 & 1,615 & 2,950 & 120 & 2,210 & 1.49 & 11 & 1904 & 111 \\
\hline Tristan de Cunha & $37.1 S$ & $12.25 \mathrm{~W}$ & 86 & 86 & 2,060 & 1 & 2,820 & 15.32 & 1 & 1811 & 315 \\
\hline Nightingale & $37.42 \mathrm{~S}$ & $12.5 \mathrm{~W}$ & 4 & 4 & 400 & 18 & 2,820 & 15.32 & 1 & 1811 & 0 \\
\hline Inaccessible & $37.25 \mathrm{~S}$ & $12.75 \mathrm{~W}$ & 12 & 12 & 600 & 6 & 2,820 & 15.32 & 1 & 1811 & 0 \\
\hline Gough & 40.33S & $9.54 \mathrm{~W}$ & 57 & 57 & 910 & 6 & 2,670 & 12.35 & 1 & 1955 & 38 \\
\hline Marion & 46.9S, & $36.75 \mathrm{E}$ & 290 & 289 & 1,230 & .45 & 1,900 & 5.53 & 6 & 1947 & 51 \\
\hline Prince Edward & $46.63 \mathrm{~S}$ & $37.95 \mathrm{E}$ & 44 & 44 & 672 & .21 & 1,900 & 5.59 & 1 & 1948 & 0 \\
\hline Cochons & $46.1 S$ & $50.23 \mathrm{E}$ & 70 & 70 & 775 & .4 & 2,740 & 4.87 & 1 & 1962 & 0 \\
\hline Apôtres & $45.97 \mathrm{~S}$ & $50.43 \mathrm{E}$ & 3 & 3 & 289 & 5.5 & 2,740 & 5.11 & 1 & 1962 & 0 \\
\hline Pinguoins & $46.5 S$ & $50.4 \mathrm{E}$ & 3.16 & 3.16 & 360 & 1.1 & 2,740 & 4.87 & 1 & 1962 & 0 \\
\hline Est & 46.43S & $52.2 \mathrm{E}$ & 130 & 130 & 1,090 & 8.75 & 2,740 & 4.75 & 1 & 1962 & 0 \\
\hline Possession & $46.42 \mathrm{~S}$ & $51.63 \mathrm{E}$ & 150 & 150 & 934 & 8.1 & 2,740 & 4.78 & 2 & 1962 & 49 \\
\hline Kerguelen & 49.37S & $69.5 \mathrm{E}$ & 7,200 & 6,450 & 1,840 & 30 & 4,110 & 3.46 & 9 & 1908 & 123 \\
\hline Heard & 53.1S, & $73.5 \mathrm{E}$ & 368 & 74 & 2,745 & 20 & 4,570 & 1.74 & 11 & 1947 & 0 \\
\hline McDonald & 53.03S, & $72.6 \mathrm{E}$ & 2.6 & 2.6 & 230 & .079 & 5,000 & 1.85 & 2 & 1947 & 0 \\
\hline Amsterdam & $37.83 \mathrm{~S}$ & $77.52 \mathrm{E}$ & 55 & 55 & 881 & .7 & 3,000 & 15.17 & 1 & 1871 & 38 \\
\hline St. Paul & $38.72 \mathrm{~S}$ & $77.53 \mathrm{E}$ & 8.1 & 8.1 & 268 & .5 & 3,000 & 14.59 & 1 & 1927 & 0 \\
\hline Macquarie & $54.62 S$ & $158.9 \mathrm{E}$ & 128 & 128 & 433 & 11.5 & 990 & 5.13 & 2 & 1948 & 57 \\
\hline Snares & $48.12 \mathrm{~S}$ & $166.6 \mathrm{E}$ & 3.28 & 3.28 & 152 & 120 & 209 & 10.95 & 1 & 1867 & 0 \\
\hline Auckland & $50.83 \mathrm{~S}$ & $166.0 \mathrm{E}$ & 626 & 626 & 668 & 18 & 465 & 9.22 & 4 & 1849 & 0 \\
\hline Campbell & $52.5 \mathrm{~S}$ & $169.17 \mathrm{E}$ & 113 & 113 & 567 & 16 & 700 & 7.83 & 5 & 1895 & 7 \\
\hline Antipodes & 49.68S, & $178.77 \mathrm{E}$ & 21 & 21 & 366 & .5 & 872 & 7.9 & 1 & 1886 & 0 \\
\hline Bounty & $47.72 \mathrm{~S}$ & $179.0 \mathrm{E}$ & 1.35 & 1.35 & 89 & 189 & 624 & 9.63 & 1 & 1880 & 0 \\
\hline
\end{tabular}

Note: For glaciation, 1 = no glaciation, $11=$ completely ice covered, and indicates extent of past glaciations of the southern ocean islands. Date of human occupation does not necessarily mean the island was subsequently occupied (see text for detail). "Distance" refers to distance to closest continent (excluding Antarctica); "date" is for first "modern" human occupation; and "occupants" is the approximate number of semipermanent annual occupants/residents. IFA $=$ ice-free area; SST $=$ sea surface temperature (mean annual).

cal stations operating on them either at all or for significant periods. Thus we used a 4-yr (1987-1990) mean of remotely sensed (Pathfinder Advanced Very High Resolution Radiometer) sea surface temperature (SST) data (University of Rhode Island Graduate School of Oceanography 1996), obtained for the $1^{\circ} \times 1^{\circ}$ grid square in which an island is located, as a measure of land surface temperature. All of the sub-Antarctic islands are highly oceanic (see Schulze 1971), and therefore SST should be a reliable guide to land surface temperature (LST). Indeed, for those islands that have had meteorological stations operating on them, and for which Stevenson Screen temperatures (LST) have been reported (e.g., De Lisle 1965; Schulze 1971; Selkirk et al. 1990), SST is an excellent predictor of LST (LST $=0.908 \mathrm{SST}+0.136, r^{2}=$ $0.963, F=360$, df $=15, P<.00001$; slope $\approx 1$, $t=-1.921, P>.43$, intercept $\approx 0, t=0.299, P>.5)$.

Because previous authors have suggested that productivity and its variability are important variables control- ling seabird species richness in the southern oceans (e.g., Chown and Gaston, in press), values for the mean and standard deviation of chlorophyll concentration, a surrogate for primary production and its variability in the oceans (see Chown and Gaston, in press), were obtained from the Coastal Zone Color Scanner data set (level 3 composite, Goddard Distributed Active Archive Center 1998). In each case, the value for the $1^{\circ} \times 1^{\circ}$ grid square, including the island of interest, was used.

Human impact (table 1) was estimated using information provided by Clark and Dingwall (1985) and Dingwall (1995). Each island was assigned a date of first modern occupation and a number of human occupants per year. The date refers either to the establishment of a permanent settlement (e.g., Falklands, Tristan da Cunha) or to the first operational year of a scientific station (e.g., Marion, Possession, and Macquarie Islands). In some cases a scientific station may have operated for some years and then closed down (e.g., Heard Island), but the 
Table 2: Species richness of plants, insects, birds, and mammals on the southern ocean islands

\begin{tabular}{|c|c|c|c|c|c|c|c|c|}
\hline \multirow[b]{2}{*}{ Islands } & \multicolumn{2}{|c|}{ Vascular plants } & \multicolumn{2}{|c|}{ Insects } & \multirow{2}{*}{$\begin{array}{l}\text { Seabirds, } \\
\text { indigenous }\end{array}$} & \multicolumn{2}{|c|}{ Land birds } & \multirow{2}{*}{$\begin{array}{l}\text { Mammals, } \\
\text { introduced }\end{array}$} \\
\hline & Indigenous & Introduced & Indigenous & Introduced & & Indigenous & Introduced & \\
\hline West Falkland & 153 & 66 & 78 & 5 & 24 & 38 & 4 & 11 \\
\hline East Falkland & 149 & 78 & 132 & 22 & 24 & 38 & 4 & 11 \\
\hline South Georgia & 25 & 53 & 21 & 8 & 26 & 2 & 1 & 3 \\
\hline Tristan da Cunha & 64 & 93 & 38 & 37 & 19 & 1 & 1 & 8 \\
\hline Nightingale & 34 & 6 & 34 & 4 & 14 & 3 & 0 & 0 \\
\hline Inaccessible & 55 & 20 & 38 & 12 & 17 & 4 & 0 & 0 \\
\hline Gough & 57 & 24 & 29 & 15 & 20 & 2 & 0 & 1 \\
\hline Marion & 23 & 17 & 19 & 16 & 27 & 1 & 0 & 2 \\
\hline Prince Edward & 21 & 2 & 18 & 3 & 28 & 1 & 0 & 0 \\
\hline Cochons & 18 & 6 & 29 & 3 & 18 & 2 & 0 & 3 \\
\hline Apôtres & 13 & 2 & 13 & 0 & 23 & 2 & 0 & 0 \\
\hline Pinguoins & 13 & 1 & 24 & 0 & 22 & 2 & 0 & 0 \\
\hline Est & 19 & 5 & 35 & 2 & 33 & 2 & 0 & 1 \\
\hline Possession & 19 & 101 & 44 & 7 & 33 & 2 & 0 & 1 \\
\hline Kerguelen & 30 & 36 & 27 & 13 & 33 & 3 & 0 & 7 \\
\hline Heard & 10 & 1 & 11 & 1 & 18 & 1 & 0 & 0 \\
\hline McDonald & 5 & 0 & 6 & 0 & 9 & 1 & 0 & 0 \\
\hline Amsterdam & 26 & 81 & 19 & 18 & 14 & 0 & 3 & 4 \\
\hline St. Paul & 9 & 10 & 13 & 9 & 10 & 0 & 1 & 3 \\
\hline Macquarie & 40 & 5 & 24 & 7 & 23 & 0 & 4 & 4 \\
\hline Snares & 20 & 2 & 137 & 8 & 17 & 6 & 4 & 0 \\
\hline Auckland & 188 & 33 & 237 & 10 & 28 & 11 & 10 & 4 \\
\hline Campbell & 140 & 88 & 176 & 19 & 22 & 4 & 10 & 2 \\
\hline Antipodes & 68 & 2 & 63 & 13 & 21 & 4 & 4 & 1 \\
\hline Bounty & 0 & 0 & 10 & 0 & 11 & 0 & 0 & 0 \\
\hline
\end{tabular}

earliest date of operation has been retained. The number of human occupants refers to either the number of humans settled on the island (e.g., Falklands, Tristan da Cunha) or the number of semipermanent occupants (usually scientific and support personnel) per year (e.g., Macquarie and Marion Islands), or to some combination of these. Because the number of tourists visiting each island is not well documented (although number of ships visiting the New Zealand islands is well known, see Dingwall 1995), and because tourism has only been significant over the last $10 \mathrm{yr}$ on a small (but rapidly increasing) proportion of the islands, tourist visitors were excluded from the data. In some cases, such as Pinguoins, infrequent visits involving few scientific personnel are made, and usually under carefully regulated conditions. Number of visitors per year was scored as 1 for such islands.

Species lists for indigenous and introduced vascular plants (angiosperms and ferns) and insects, excluding Collembola (given as species richness in table 2), were compiled from the primary systematic literature (e.g., Kuschel 1964; Christophersen 1968), from reviews of the biotas of the southern ocean islands (e.g., Gressitt 1964, 1970, 1971; Greene and Walton 1975; Robinson 1984;
Chown 1990; Greenslade 1990; Selkirk et al. 1990; Carcaillet 1993; Patrick 1994), and from unpublished records (e.g., Marchand 1995). Over 250 references were consulted and the database is available from us on request. In all cases, care was taken to identify recent synonymies and additions to the biotas involving both new records and new species. A species was considered introduced if any authority regarded it to be so. Some cases were necessarily polemical (e.g., Chown and Avenant 1992), but we erred in favor of the introduction scenario. Introduced species that are known to exist only in stored products or within buildings at scientific stations, or that were planted in gardens and have not reproduced, were excluded (e.g., plants: Allium cepa L. [Liliaceae]; insects: Blatella germanica [L.] [Blattodea, Blatellidae]).

Species lists for the avifauna were compiled as above (see, e.g., Prince and Croxall 1983; Woods 1988; Weimerskirch et al. 1989; Turbott 1990), and the fauna was divided into three groups. Seabirds included all penguins, procellariiforms, skuas, gulls, terns, and cormorants. Indigenous land birds included all waders and sheathbills, raptors, ducks, grebes, herons, owls, parrots, and passerines that are thought to be indigenous to the islands. In- 


\section{The American Naturalist}

troduced land birds had the same taxonomic coverage as the indigenous land bird species, but here birds that are known to have been introduced to the islands (see above for rationale), and/or that are known to have introduced themselves to the islands, subsequent to a humanmediated introduction to a nearby land mass (e.g., cardueline finches to New Zealand and its surrounding islands; Turbott 1990), were included (table 2).

Species lists for introduced mammals were compiled as above (e.g., Bonner 1984; Chapuis et al. 1994; Clark and Dingwall 1985; Dingwall 1995; Young 1995; table 2). In one case (feral cats on Marion Island), a species was included that has been hunted to extinction by humans in a controlled eradication program (see Bloomer and Bester 1992). Indigenous mammals were excluded from the analyses because most islands have two or three seal species breeding on them (King 1983), and most lack indigenous terrestrial mammals (Clark and Dingwall 1985).

Rather than assessing the merits of the various models that have been proposed for species-area relationships (e.g., Connor and McCoy 1979; He and Legendre 1996), we chose the most common, log-log approach. Thus all data, with the exception of distance from the nearest continent, sea surface temperature, and date of first occupation, were logarithmically transformed (base e), and least-squares linear regressions were used to investigate relationships between the physical and human occupancy variables and introduced and indigenous plant species richness. Similar analyses were conducted for introduced and indigenous insect species richness, bird species richness, and introduced mammal species richness, although species richness of indigenous plants was included in the analyses of the insect data, and both indigenous plant and indigenous insect species richness were included in the analyses of land bird richness. For tabulated regression results, we undertook sequential Bonferroni corrections (see Rice 1989). However, because the models were not chosen from a full analysis of all possible combinations of variables, it should be kept in mind that this correction is likely to underestimate the significance of the models.

Subsequently, the data were explored in greater depth using models that included either two or three explanatory variables. Independent variables were selected a priori, based on an assessment of which variables were biologically most meaningful. For example, mean chlorophyll concentration of the oceans was excluded from the analyses of the terrestrial taxa. Likewise, in the case of the introduced plant, insect, bird, and mammal species, minimum age of the islands and extent of past glaciation were excluded from these analyses on the grounds that they are unlikely to be biologically significant for recently introduced species. Similarly, human occupancy variables were excluded from analyses of the indigenous biotas. With regard to introduced species, indigenous species of the same taxon were also assessed in the multivariate models to ascertain the likelihood of negative interactions between indigenous and introduced species.

In all analyses, most two-variable models were assessed, but because the subsequent improvement obtained with three-variable models was only slight, few of these were included (e.g., altitude + distance + SST to explain seabird species richness). In models including more than one explanatory variable, the interaction between the explanatory variables was also assessed. Only those models with the highest coefficients of determination and where each independent variable was significant after accounting for the effects of the other independent variables (using a $t$-test in an ANOVA of the partitioned sums of squares; see Payne et al. 1993; Sokal and Rohlf 1995) were considered further in each case. Furthermore, in those cases where individual data points either had large residuals (standardized residuals of $<-2$ or $>2$ ) or a great leverage (more than the value of $2 \times$ number of parameters/number of samples; Payne et al. 1993), the models were reexamined excluding data for these islands. Less confidence was placed in models where outliers had a large effect, although only those models including all islands were subject to scrutiny.

\section{Results}

Among the physical and human occupancy variables, larger islands tend to rise to the highest elevations, were more heavily glaciated, and have significantly more permanent human occupants than smaller ones (table 3), while the coldest islands were the last to be occupied by humans. A significant positive correlation between the mean and standard deviation of chlorophyll concentration has been documented elsewhere (Chown and Gaston, in press), but a significant positive correlation between mean chlorophyll concentration and island age was also observed but was difficult to interpret (table 3).

After Bonferroni correction, none of the physical variables explained a statistically significant portion of the variance in indigenous vascular plant species richness in the individual analyses (table 4), although area was on the verge of significance. Given that the correction probably underestimates the significance of these relationships (see "Methods"), we proceeded with an examination of the effects of area. Bounty was clearly an outlier in this data set (fig. 1), and after its removal the $r^{2}$ of the relationship declined $\left(r^{2}=0.27\right)$, and distance explained most variance $\left(r^{2}=0.48\right)$. Nonetheless, it was evident that although there is a relationship between area and 
Table 3: Correlation matrix for physical and human occupancy variables for the southern ocean islands

\begin{tabular}{|c|c|c|c|c|c|c|c|c|c|c|c|}
\hline Variable & $\begin{array}{l}\text { Log } \\
\text { area }\end{array}$ & $\begin{array}{c}\log \\
\text { altitude }\end{array}$ & $\begin{array}{c}\log \\
\text { glaciation }\end{array}$ & $\begin{array}{l}\text { Log } \\
\text { age }\end{array}$ & SST & Distance & $\begin{array}{c}\log \\
\text { occupants }\end{array}$ & Date & $\begin{array}{c}\log \\
\text { CHLM }\end{array}$ & $\begin{array}{c}\log \\
\text { CHLSD }\end{array}$ & $\begin{array}{c}\log \\
I N D V P\end{array}$ \\
\hline Log altitude & $.71^{\star \star \star}$ & * & & & & & & & & & \\
\hline Log glaciation & $.64^{\star \star \star}$ & $.58^{\star \star}$ & * & & & & & & & & \\
\hline Log age & $.44^{\star}$ & .03 & .31 & * & & & & & & & \\
\hline SST & -.29 & -.24 & $-.55^{\star \star}$ & -.03 & * & & & & & & \\
\hline Distance & -.17 & .35 & .10 & $-.50^{\star}$ & -.18 & * & & & & & \\
\hline Log occupants & $.74^{\star * \star}$ & $.51^{\star *}$ & .35 & $.41^{\star}$ & -.02 & -.14 & * & & & & \\
\hline Date & -.14 & .04 & .07 & $-.44^{*}$ & $-.64^{\star \star \star}$ & .36 & -.24 & * & & & \\
\hline Log CHLM & $.53^{\star *}$ & .08 & .29 & $.77^{\star \star \star}$ & -.27 & $-.43^{*}$ & $.49^{*}$ & -.26 & * & & \\
\hline Log CHLSD & $.56^{\star *}$ & .25 & $.54^{\star *}$ & $.57^{\star \star}$ & -.33 & -.25 & $.46^{*}$ & -.20 & $.83^{\star * *}$ & * & \\
\hline Log INDVP & $.61^{\star *}$ & .39 & .19 & .26 & .21 & -.39 & $.45^{\star}$ & $-.45^{\star}$ & .28 & .32 & * \\
\hline Log INTVP & $.71^{\star \star \star}$ & $.56^{\star *}$ & .29 & .30 & .27 & -.17 & $.75^{\star \star \star}$ & $-.40^{*}$ & .34 & $.43^{*}$ & $.68^{\star * *}$ \\
\hline
\end{tabular}

Note: Values in bold type indicate significance at the .05 level after a sequential Bonferroni correction has been applied. Area $=$ ice-free area, $\mathrm{SST}=$ sea surface temperature, $\mathrm{CHLM}=$ mean chlorophyll concentration $\left(\mathrm{mg} \mathrm{mm}^{-3}\right), \mathrm{CHLSD}=\mathrm{SD}$ of mean chlorophyll concentration, $\mathrm{INDVP}=$ indigenous vascular plant species richness, and INTVP $=$ introduced vascular plant species richness.

${ }^{*} P<.05$.

${ }^{* *} P<.01$.

$* * * P<.001$

species richness, the latter tends to be lower on the subAntarctic than on the more temperate islands (fig. 1). Indeed, inclusion of both area and sea surface temperature in the regression model explained a significant portion of the variance in species richness and was relatively insensitive to outlier removal (table 5). Because of an interaction between these two variables, the best model included this interaction term. In contrast, although models in- cluding area and altitude or area and distance had higher coefficients of determination than the combination of area and SST (table 5), they were sensitive to outlier removal (removal of Bounty resulted in coefficients of determination of 0.48 compared with 0.63 in the former case, and 0.61 compared with 0.43 in the latter).

For introduced plant species, a significant proportion of the variance of richness was explained individually by

Table 4: Coefficient of determination and significance level of the relationship between $\log (n+1)$ species richness and the physical, human occupancy, and plant species richness variables

\begin{tabular}{|c|c|c|c|c|c|c|c|c|}
\hline \multirow[b]{2}{*}{ Regression } & \multicolumn{2}{|c|}{ Plants } & \multicolumn{2}{|c|}{ Insects } & \multicolumn{2}{|c|}{ Land birds } & \multirow{2}{*}{$\begin{array}{l}\text { Mammals, } \\
\text { introduced }\end{array}$} & \multirow{2}{*}{$\begin{array}{l}\text { Seabirds, } \\
\text { indigenous }\end{array}$} \\
\hline & Indigenous & Introduced & Indigenous & Introduced & Indigenous & Introduced & & \\
\hline Log area & $.375^{\star *}$ & $.502^{\star \star *}$ & $.166^{*}$ & $.296^{\star *}$ & $.249^{*}$ & .107 & $.643^{\star * *}$ & $.441^{\star * *}$ \\
\hline Log altitude & .153 & $.318^{\star *}$ & .001 & $.182^{\star}$ & .005 & .01 & $.194^{\star}$ & $.306^{\star \star}$ \\
\hline Log age & .07 & .09 & $.215^{\star \star}$ & .01 & $.398^{\star * *}$ & .120 & .102 & .06 \\
\hline Log glaciation & .03 & .09 & .005 & .02 & .03 & .02 & .09 & .137 \\
\hline SST & .04 & .07 & .05 & $.212^{\star}$ & .001 & .04 & .005 & $.179^{\star}$ \\
\hline Distance & .152 & .03 & $.468^{\star * *}$ & .08 & $.21^{*}$ & $.481^{\star \star *}$ & .06 & .05 \\
\hline Date & $.205^{\star}$ & $.158^{\star}$ & $.246^{\star}$ & $.220^{*}$ & $.228^{\star}$ & $.192^{\star}$ & .100 & .03 \\
\hline Log occupants & $.198^{*}$ & $.551^{\star \star *}$ & .05 & $.373^{\star *}$ & .08 & .06 & $.591^{\star \star *}$ & .137 \\
\hline Log INDVP & $\cdots$ & $\ldots$ & $.615^{\star \star *}$ & $.490^{* * *}$ & $.463^{\star * *}$ & $.404^{\star \star *}$ & $.330^{\star *}$ & $.238^{\star}$ \\
\hline Log insects & $\ldots$ & $\ldots$ & $\ldots$ & $\ldots$ & $.553^{\star * *}$ & $.550^{\star \star *}$ & $\ldots$ & $\ldots$ \\
\hline Log CHLM & $\ldots$ & $\ldots$ & $\ldots$ & $\ldots$ & $\ldots$ & $\ldots$ & $\ldots$ & .140 \\
\hline Log CHLSD & $\ldots$ & $\cdots$ & $\cdots$ & $\ldots$ & $\ldots$ & $\cdots$ & $\ldots$ & $.158^{\star}$ \\
\hline
\end{tabular}

Note: Values in bold are significant $(P<.05)$ after a sequential Bonferroni correction. SST $=$ sea surface temperature, CHLM $=$ mean chlorophyll concentration $\left(\mathrm{mg} \mathrm{mm}^{-3}\right), \mathrm{CHLSD}=\mathrm{SD}$ of mean chlorophyll concentration, and INDVP $=$ indigenous vascular plant species richness.

${ }^{\star} P<.05$.

${ }_{* *}^{*} P<.01$

${ }^{* * *} P<.001$. 


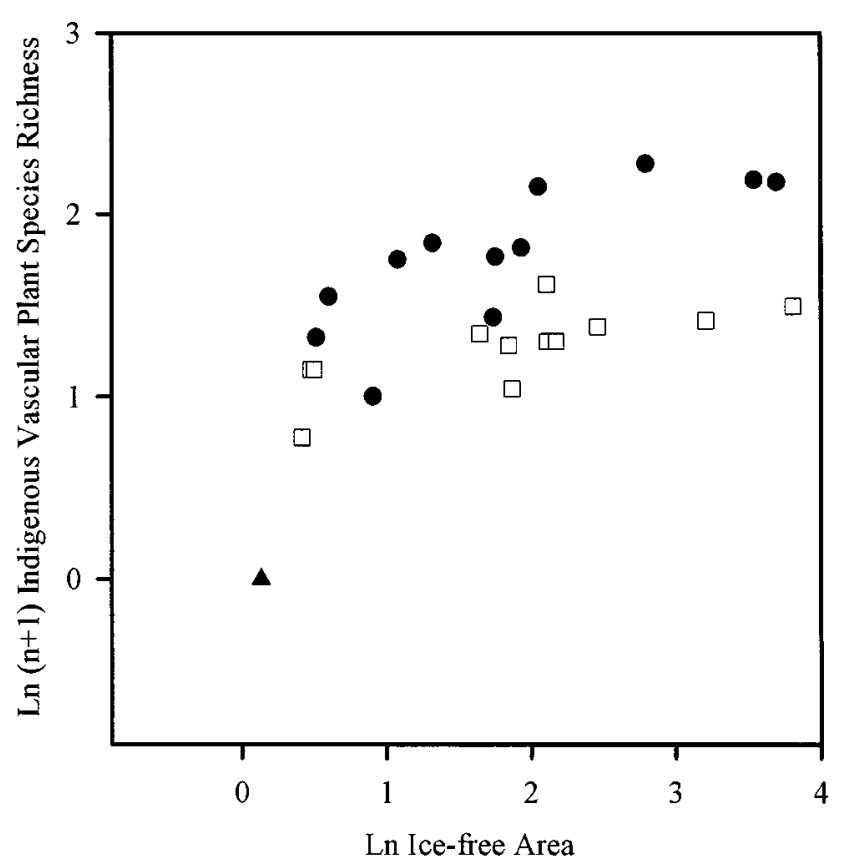

Figure 1: Bivariate plot of $\ln (n+1)$ indigenous vascular plant species richness on $\ln$ ice-free area for the southern ocean islands. The rate of increase of species richness is higher for the temperate (circles) than for the colder islands (squares). Bounty Island (triangle) is a significant outlier.

number of occupants per year and by ice-free area (table 4). Combination of these two variables did not improve the fit of the model $\left(r^{2}=0.57\right)$, but inclusion of area and SST did $\left(r^{2}=0.73\right.$; table 5$)$. A model including number of occupants and SST only resulted in a lower coefficient of determination $\left(r^{2}=0.60\right)$ than that provided by the previous model. None of these models were sensitive to outlier removal. Indigenous plant species richness did not enter as a significant term in any of these models.

Plant species richness and distance to the closest continent were significant in the individual bivariate analyses with indigenous insect species richness (table 4). Likewise, inclusion of both independent variables yielded the multifactor model with the highest coefficient of determination $\left(r^{2}=0.75\right.$; table 5$)$. This model was relatively insensitive to the removal of outliers.

In the case of introduced insect species, a significant correlation was found only with indigenous plant species richness (table 4). Multiple regression models with the highest significance were those that included area and SST $\left(r^{2}=0.69\right)$, number of occupants and SST $\left(r^{2}=\right.$ $0.56)$, indigenous vascular plants and SST $\left(r^{2}=0.56\right)$, and indigenous vascular plants, date of first occupation, and their interaction term $\left(r^{2}=0.60\right.$; table 5$)$. Although indigenous species entered one of the models as a mar-

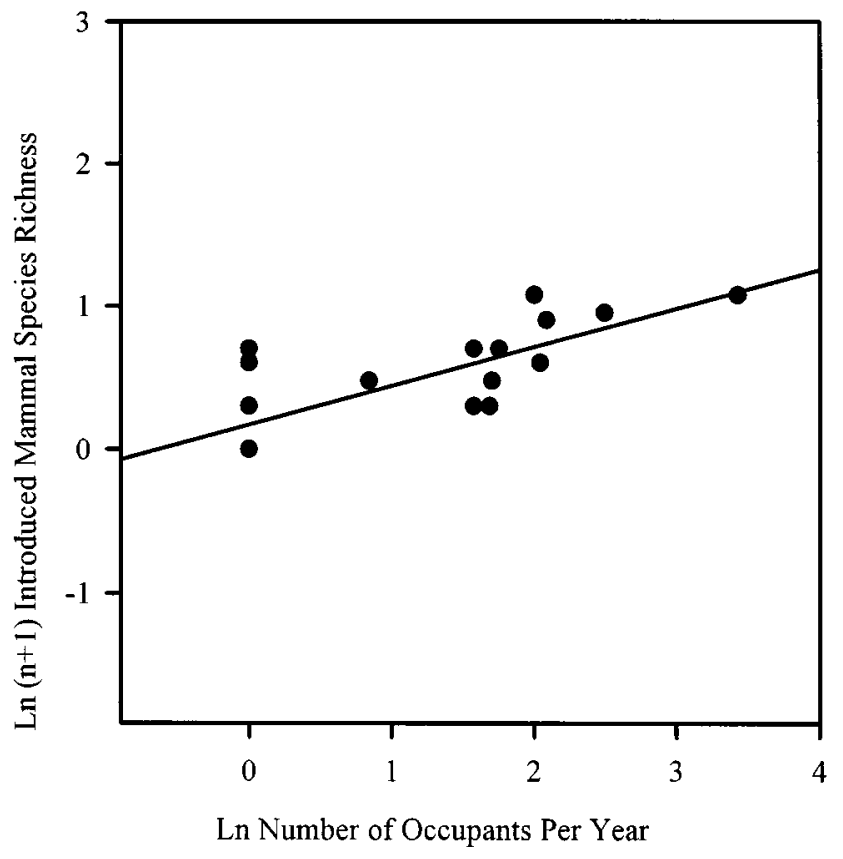

Figure 2: Bivariate plot of $\ln (n+1)$ introduced mammal species richness on ln number of occupants per year for the southern ocean islands (see text for further detail).

ginally significant term, its regression coefficient was positive (table 5).

For seabirds, individual correlations were significant for area only (table 4). However, after removal of the outlier formed by McDonald Island, SST also explained a significant proportion of the variance in the data $\left(r^{2}=\right.$ 0.40 ). Likewise, removal of outliers from the regression on altitude also had a large effect on the coefficient of determination (reducing it to 0.15), and this variable was excluded. The multifactor model with the highest coefficient of determination was one that included mean chlorophyll concentration and its interaction term with area (table 5).

Individually, indigenous insect species richness, indigenous plant species richness, and minimum age of the island explained significant portions of the variance of indigenous land bird species richness across islands (table 4). The two multifactor models that gave the best fit included indigenous insects and age $\left(r^{2}=0.63\right)$, and age and its interaction term with indigenous insects $\left(r^{2}=\right.$ 0.73 ; table 5).

For introduced land birds, indigenous insect species richness, distance to the nearest continent, and indigenous vascular plant species richness were significant in the individual correlation analyses (table 4). Likewise, the multifactor models that had the highest coefficients of 
Table 5: Results of the multiple regression analyses

\begin{tabular}{|c|c|c|}
\hline Taxon and model & $\mathrm{r}^{2}$ & $\begin{array}{c}\mathrm{r}^{2} \\
\text { (outliers removed) }\end{array}$ \\
\hline \multicolumn{3}{|l|}{ Indigenous plants: } \\
\hline$y=-3.07+.856$ altitude +2.341 area -.3116 altitude $\times$ area & .63 & .48 \\
\hline$y=1.102+.345 \times$ area $+.107 \times$ SST & .51 & .51 \\
\hline$y=2.131+.04190$ area $\times$ SST & .56 & .56 \\
\hline$y=3.828+.1534$ area -.000096 distance & .43 & .61 \\
\hline \multicolumn{3}{|l|}{ Introduced plants: } \\
\hline$y=-1.086+.5343$ area $+.1762 \mathrm{SST}$ & .73 & .87 \\
\hline \multicolumn{3}{|l|}{ Indigenous insects: } \\
\hline$y=2.593-.000313$ distance +.477 indigenous plants & .75 & .74 \\
\hline \multicolumn{3}{|l|}{ Introduced insects: } \\
\hline$y=-.698+.3227$ area +.1603 SST & .69 & .74 \\
\hline$y=.476+.2729$ occupants +.1119 SST & .56 & .61 \\
\hline$y=-.717+.593$ indigenous plants +.0782 SST & .56 & .50 \\
\hline$y=76-19.11$ indigenous plants -.0041 date +.01405 indigenous plants $\times$ date & .60 & .68 \\
\hline$y=-.744+.2392$ occupants +.0935 SST +.415 indigenous insects & .66 & .67 \\
\hline \multicolumn{3}{|l|}{ Indigenous land birds: } \\
\hline$y=-1.119+.613$ indigenous insects +.1310 age & .63 & .58 \\
\hline$y=.741-.460$ age +.1724 age $\times$ indigenous insects & .73 & .59 \\
\hline \multicolumn{3}{|l|}{ Introduced land birds: } \\
\hline$y=.031+.4497$ indigenous plants -.0001292 distance $\times$ indigenous plants & .70 & .71 \\
\hline$y=-.433+.510$ indigenous insects -.0000993 distance $\times$ indigenous insects & .66 & .67 \\
\hline $\begin{array}{l}y=-.11+.610 \text { indigenous plants }-.00015 \text { distance } \times \text { indigenous plants }-.228 \text { in } \\
\text { land birds }\end{array}$ & .74 & .74 \\
\hline \multicolumn{3}{|l|}{ Seabirds: } \\
\hline$y=3.3861+.699$ CHLM -.1159 area $\times$ CHLM & .65 & .64 \\
\hline \multicolumn{3}{|l|}{ Introduced mammals: } \\
\hline$y=-.849+.3122$ area +.626 SST & .72 & .69 \\
\hline$y=-.074+.1781$ area +.1385 occupants & .69 & .67 \\
\hline
\end{tabular}

Note: Only those models giving the highest coefficients of determination are shown. The $r^{2}$ of the model excluding outliers is given in the second column. Where the parameters for the model excluding outliers is given, this is indicated in boldface. In these cases, the first $r^{2}$ column still indicates the coefficient of determination for the model including all islands. CHLM $=$ mean chlorophyll concentration $\left(\mathrm{mg} \mathrm{mm}^{-3}\right)$, SST $=$ sea surface temperature.

determination included indigenous vascular plants and its interaction with distance $\left(r^{2}=0.70\right)$ and indigenous insects and its interaction term with distance $\left(r^{2}=0.66\right.$; table 5). Although area and distance together also explained a substantial portion of the variance in introduced land bird species $\left(r^{2}=0.56\right)$, this regression gave nonrandom residuals and was sensitive to outlier removal. In one case (see table 5), indigenous land bird species entered the model as a significant term with a negative coefficient and caused a notable increase in the coefficient of determination.

Variation in introduced mammal species richness was significantly accounted for by individual regressions on area and number of occupants (table 4; fig. 2). The multifactor model including both area and occupants resulted in an increase in the coefficient of determination compared with a model including area only $\left(r^{2}=0.69\right.$ and 0.64 , respectively), as did the model including area and SST $\left(r^{2}=0.72\right)$.

\section{Discussion}

One of the primary concerns in an analysis using data from remote islands, of which the biotas have only recently been documented (see table 2), is the extent to which the faunas and floras have been thoroughly surveyed (Connor and Simberloff 1978; Gaston 1996). Given the extent of biological research on most of the islands (see, e.g., Holdgate 1960, 1965; Gressitt 1964, 1970, 1971; Gremmen 1981; Lewis Smith 1984; Robinson 1984; Crafford et al. 1986; Woods 1988; Greenslade 1990; Selkirk et al. 1990; Turbott 1990; Patrick 1994), we are con- 


\section{The American Naturalist}

vinced that for the taxa used here the data are sound for most of the islands. The only exceptions may be the insects and plants of Amsterdam and St. Paul, for which modern reviews are not readily available (see Decante et al. 1987 and Marchand 1995 for older literature and data on mammals and birds). Nonetheless, these islands were rarely identified as significant outliers in the analyses, suggesting that inventories for the taxa examined are adequate.

In consequence, and given our choice of taxa, we are in a considerably better position to examine the "anomalous" nature of indigenous southern ocean island biotas than were previous workers (see the introduction to this article). To do this, we have relied heavily on bivariate analyses and on sequential assessment of most two-factor models and, in some cases, three-factor models, the latter usually incorporating the interaction term between the independent variables in the two-factor model. We chose not to use stepwise variable selection techniques because these make a number of questionable assumptions, and their results may often have doubtful biological validity (see James and McCulloch 1990). Rather, in being faced with a data set of intercorrelated variables, we have followed the advice of James and McCulloch (1990) in considering variables separately, with the use of Bonferroni corrections, and in combination, and in relying on biological knowledge to assist with interpretation of the results.

\section{Indigenous Biotas}

In combination, area and SST explained the most variance in vascular plant species richness, and this model was relatively insensitive to outliers. This suggests that species richness increases with area for the southern ocean islands but that this increase is more rapid on the temperate islands than on the colder ones (contra Abbott 1974). Thus it appears that the effect of area on habitat heterogeneity and possibly population size, as well as the severity of the climate of an island, play important roles in determining species richness on these islands, as is the case elsewhere (see discussion in Rosenzweig 1995).

In combination, vascular plant species richness and distance to the nearest continent accounted for $75 \%$ of the variance in insect species richness (see also Abbott 1974; Williams 1982; Kuschel 1991). Here, the poor relationship between insect species richness and area indicates that vascular plant species richness per se is accounting for variation in insect species richness. This seems likely, given that a considerable proportion of the insects on all of the southern ocean islands are herbivores (Gressitt 1970; Chown 1990; Kuschel 1991; Patrick 1994), of which many are at least oligophages restricted to vas- cular plant species (Crafford and Scholtz 1986; Patrick 1994), although with some notable exceptions (e.g., Kuschel 1964, 1971; Tréhen et al. 1985; Crafford et al. 1986; Chown 1989; Chown and Block 1997). In these latter cases, vascular plant species richness may be acting as a surrogate for total plant species richness, hence explaining a significant portion of the variance in insect species richness (see Gaston 1992).

Distance to the nearest continent also explained a significant proportion of the variance in insect species richness. This suggests that dispersal has been an important factor contributing to the development of insect biotas on these islands, as was argued by Gressitt (1970; but see Jeannel 1964; Brundin 1987; Chown 1994) and as is the case for most other oceanic islands (see, e.g., Peck and Kukalová-Peck 1990; Wagner and Funk 1995). Although a variety of authors has commented on the elevated levels of flightlessness in sub-Antarctic insect faunas (Gressitt 1970; Carlquist 1974; Roff 1990; Kuschel and Chown 1995), strong selection for reduced dispersal ability is not uncommon in vagile taxa that have recently colonized islands (Cody and Overton 1996).

With regard to seabirds, it is not surprising that area and sea surface temperature contributed most to explaining species richness across this region in the individual analyses and that mean chlorophyll concentration and its interaction with area provided the best-fit multifactor model. Seabirds tend to be limited by nest site availability on southern ocean islands (Miskelly 1984; Jouventin 1990; Warham 1996), and area provides an effective surrogate measure thereof. At large scales, strong relationships between primary productivity (and sea surface temperature), measures of resource abundance, and seabird species richness and abundance have previously been found (Abrams 1985; Pakhomov and MacQuaid 1996; Chown and Gaston, in press).

Given that insects (and to some extent plants) form the food of the majority of the land birds (including sheathbills; Abbott 1974; Burger 1978), and that insect and plant species richness are interrelated, it is perhaps unsurprising that these variables are important in the individual correlation analyses of indigenous land bird species richness (contra Abbott 1974). However, the most significant multifactor models included indigenous insects and age of the islands, suggesting that insect species richness per se, time available for faunal accumulation, and, to a limited extent, in situ evolution of endemic bird species (see, e.g., Wace and Holdgate 1976; Woods 1988; Turbott 1990) have contributed to elevated species richness on the older islands.

In sum, and unlike previous workers, we find that conventional island biogeographic variables (MacArthur and Wilson 1967; Rosenzweig 1995) explain a significant 
proportion of the variance in indigenous plant (area), insect (distance to the nearest continent), seabird (area), and land bird (island age) species richness on southern ocean islands at this scale. Furthermore, the extent of past glaciations on the islands appears to have had little effect on the indigenous biotas, although a direct test of this hypothesis, involving (largely unavailable) accurate data on the extent of glaciers during, and the timing of, the last glacial maximum on each island, has not been undertaken. Nonetheless, our data do provide support for the idea that current climatic severity of the islands has an impact on species richness (Gressitt 1970; Abbott 1974; see also Wiencke et al. 1994), at least as far as plants, seabirds, and land birds are concerned.

\section{Introduced Biotas}

In the case of the introduced vascular flora, area and number of human occupants explained most variance in the number of species in the bivariate analyses, and indeed these variables were virtually interchangeable. As a consequence of this, and the high correlation between these independent variables, it is not entirely clear which one of them is of most significance in explaining species richness. Furthermore, in combination, area and number of occupants explained less of the variance in the data than did area and SST. This suggests that, on climatically severe islands, propagules have a lower probability of surviving than on more temperate ones. More important, islands with the largest area tend to be most susceptible to the successful establishment of alien vascular plants because of both higher habitat heterogeneity and larger numbers of human occupants.

Indigenous vascular plant species richness explained most of the variance in introduced insect species richness in the bivariate analyses. In combination with either SST or date of first modern human occupation, indigenous vascular plant species was also of considerable significance in explaining introduced insect species richness in the multifactor models. Nonetheless, both area and number of occupants, each in combination with SST, also provided equal or better fits to the data. Here, as in the previous case, it appears that alien insects have a higher chance of establishing on the temperate than on the colder islands. It also appears that islands with the largest area tend to be most susceptible to establishment of alien insects because of higher numbers of vascular plant species and because they house larger numbers of human occupants. Alternatively, high alien insect species richness also seems to be associated with islands that are rich in vascular plant species and that have had a long history of modern human occupation. In sum, these relationships suggest to us that vascular plant species richness is im- portant in determining alien insect species richness and that this relationship is modified both by the extent of human activity on an island and by the island's climatic severity.

In a similar way, introduced mammal species richness covaries significantly with area and number of occupants in the bivariate analyses, but SST enters the multifactor model, together with area, to explain more of the variance in mammal species richness than do area and occupants in combination. Again it seems likely that introduced mammals have a higher likelihood of survival on warmer islands and that larger islands are likely to have larger numbers of alien species because of larger numbers of occupants.

For introduced land bird species, the picture is rather different. Because many of the species involved are European ones, which were introduced to New Zealand (Turbott 1990) and subsequently crossed to the New Zealand sub-Antarctic islands themselves (Young 1995), distance to the nearest continent is highly significant in the individual and multifactor analyses. Mostly passerines, these represent a mixture of plant and insect feeding species, and it has been shown that insect species richness also depends to a large extent on plant species richness. Hence, the importance of both plant and insect species richness in explaining variation in the numbers of introduced bird species. Nonetheless, the significant negative influence of indigenous land bird species richness on introduced species richness suggests that the larger the number of indigenous species the less likely the successful establishment of introductions (see also Brown 1995).

In sum, it appears that climatically temperate islands are more susceptible to alien invasions than are cooler ones and that area and the number of human occupants per year (and the interaction between them) are important determinants of the numbers of species introduced to the islands. For mammals this relationship is unsurprising, given that many of the mammals were purposefully introduced (Bonner 1984; Leader-Williams 1988; Bloomer and Bester 1992; Chapuis et al. 1994). In the case of plants and insects, the likely relationship between number of human occupants per year and species richness is of considerable concern. Most of the introduced plant and insect species appear to have reached the islands accidentally, as a consequence of human activities (e.g., Gremmen 1981; Carcaillet 1993; Chown and Language 1994; Patrick 1994; Marchand 1995). Even though the level of human activity has been low compared with most other islands (see table 1), the number of introductions has been considerable (see, e.g., Possession Island for plants, Marion Island for insects), resulting, in the most extreme cases, in an order of magnitude increase in species richness. Although many of these introduced 


\section{The American Naturalist}

plant and insect species seem to be having a minimal impact on ecosystem functioning, at least some of them radically transform these island systems (see, e.g., Ernsting et al. 1995; Gremmen 1997; Gremmen et al., in press).

Two studies (Chown and Language 1994; Kennedy 1995) have argued that as global warming causes an increase in temperature at the southern ocean islands (see Smith and Steenkamp 1990 and Frenot et al. 1997 for data), the likelihood of introduced species becoming established and established species having more pronounced impacts will increase. If this is the case (and our data support the idea that the more temperate southern ocean islands are most susceptible to establishment of alien species), and if number of occupants per year has a pronounced impact on the number of introductions to the islands (see above), then any increase in numbers of visitors to the islands may present considerable conservation problems through elevated levels of establishment of introduced species. Currently, the numbers of tourists to these islands, and the pressure for tourism to them, is increasing rapidly (Dingwall 1995). This suggests that both tourism and scientific visits to these islands should be more closely regulated and that at least some of the islands should not be visited at all.

\section{Acknowledgments}

This work would not have been possible without the kind assistance of C. M. Phillips and J. Harvey, librarians at the British Antarctic Survey (BAS; Cambridge) and the Natural History Museum (NHM; London), respectively. Thanks are due also to D. W. H. Walton and W. Block (BAS) and M. J. Scoble (NHM) for assistance at these institutions. P. Vernon (Université de Rennes) and G. Robinson (NHM) provided unpublished data or commented on data quality, and K. Casey (University of Rhode Island) prepared the sea surface temperature data in a format suitable to us. We thank M. A. McGeoch (University of Pretoria) and P. J. M. Greenslade (Commonwealth Scientific and Industrial Research Organisation, Division of Entomology, Australia) for commenting on the manuscript, as well as S. Harrison, M. L. Cody, and an anonymous referee, whose comments improved the manuscript. This research was partly undertaken and supported while S.L.C. was on a Commonwealth Staff Development Fellowship at the University of Sheffield, and he thanks J. A. Lee for provision of facilities. S.L.C. is supported by the Department of Environmental Affairs and Tourism and the University of Pretoria (South Africa); N.J.M.G. is partly supported by the Netherlands Antarctic Research Program; and
K.J.G. is a Royal Society University Research Fellow (United Kingdom).

\section{Literature Cited}

Abbott, I. 1974. Numbers of plant, insect and land bird species on nineteen remote islands in the Southern hemisphere. Biological Journal of the Linnean Society 6:143-152.

Abrams, R. W. 1985. Environmental determinants of pelagic seabird distribution in the African sector of the southern ocean. Journal of Biogeography 12: 473-492.

Barrat, A., and J. L. Mougin. 1974. Données numériques sur la zoogéographie de l'avifaune antarctique et subantarctique. Comité National Français des Recherches Antarctiques 33:1-18.

Bloomer, J. P., and M. N. Bester. 1992. Control of feral cats on sub-Antarctic Marion Island, Indian Ocean. Biological Conservation 60:211-219.

Bonner, W. N. 1984. Introduced mammals. Pages 237278 in R. M. Laws, ed. Antarctic ecology. Vol. 1. Academic Press, London.

Brown, J. H. 1995. Macroecology. University of Chicago Press, Chicago.

Brundin, L. Z. 1987. Phylogenetic biogeography. Pages 343-369 in A. A. Myers, and P. S. Giller, eds. Analytical biogeography: an integrated approach to the study of animal and plant distributions. Chapman \& Hall, London.

Burger, A. E. 1978. Terrestrial invertebrates: a food resource for birds at Marion Island. South African Journal of Antarctic Research 8:87-99.

- 1985. Terrestrial food webs in the sub-Antarctic: island effects. Pages 582-591 in W. R. Siegfried, P. R. Condy, and R. M. Laws, eds. Antarctic nutrient cycles and food webs. Springer, Berlin.

Carcaillet, C. 1993. Les plantes allochtones envahissantes de l'archipel Crozet, Océan Australe. Revue d'Ecologie la Terre et la Vie 48:3-20.

Carlquist, S. 1974. Island biology. Columbia University Press, New York.

Chapuis, J. L., P. Boussès, and G. Barnard. 1994. Alien mammals, impact and management in the French subantarctic islands. Biological Conservation 67:97-104.

Chown, S. L. 1989. Habitat use and diet as biogeographic indicators for subantarctic Ectemnorhinini (Coleoptera: Curculionidae). Antarctic Science 1:23-30.

- 1990. Possible effects of Quaternary climatic change on the composition of insect communities of the South Indian Ocean Province Islands. South African Journal of Science 86:386-391. 
1994. Historical ecology of subantarctic weevils: patterns and processes on isolated islands. Journal of Natural History 28:411-433.

1997. Sub-Antarctic weevil assemblages: species, structure and survival. Pages 152-161 in B. Battaglia, J. Valencia, and D. W. H Walton, eds. Antarctic communities: species, structure and survival. Cambridge University Press, Cambridge.

Chown, S. L., and N. Avenant. 1992. Status of Plutella xylostella at Marion Island six years after its colonization. South African Journal of Antarctic Research 22: 37-40.

Chown, S. L., and W. Block. 1997. Comparative nutritional ecology of grass-feeding in a sub-Antarctic beetle: the impact of introduced species on Hydromedion sparsutum from South Georgia. Oecologia (Berlin) 111:216-224.

Chown, S. L., and K. J. Gaston. In press. Patterns in procellariiform diversity as a test of species-energy theory in marine systems. Evolutionary Ecology.

Chown, S. L., and K. Language. 1994. Newly established insects on sub-Antarctic Marion Island. African Entomology 2:57-60.

Chown, S. L., and V. R. Smith. 1993. Climate change and the short-term impact of feral house mice at the subAntarctic Prince Edward Islands. Oecologia (Berlin) 96:508-516.

Chown, S. L., K. J. Gaston, and P. H. Williams. 1998. Global patterns in the species richness of pelagic seabirds: the Procellariiformes. Ecography (in press).

Christophersen, E. 1968. Flowering plants from Tristan da Cunha. Results of the Norwegian Scientific Expedition to Tristan da Cunha, 1937-1938 55:1-29.

Clark, M. R., and P. R. Dingwall. 1985. Conservation of islands in the southern ocean: a review of the protected areas of insulantarctica. International Union for Conservation of Nature and Natural Resources, Gland.

Cody, M. L., and J. McC. Overton. 1996. Short-term evolution of reduced dispersal in island plant populations. Journal of Ecology 84:53-61.

Connor, E. F., and E. D. McCoy. 1979. The statistics and biology of the species area relationship. American Naturalist 113:791-833.

Connor, E. F., and D. Simberloff. 1978. Species number and compositional similarity of the Galapagos flora and avifauna. Ecological Monographs 48:219-248.

Cooper, J., and P. G. Ryan. 1994. Management plan for the Gough Island Wildlife Reserve. Government of Tristan da Cunha, Edinburgh, Tristan da Cunha.

Crafford, J. E., and C. H. Scholtz. 1986. Impact of Embryonopsis halticella Eaton larvae (Lepidoptera: Ypono- meutidae) feeding in Marion Island tussock grassland. Polar Biology 6:191-196.

Crafford, J. E., C. H. Scholtz, and S. L. Chown. 1986. The insects of sub-Antarctic Marion and Prince Edward Islands; with a bibliography of entomology of the Kerguelen biogeographical province. South African Journal of Antarctic Research 16:42-84.

Decante, F., P. E. Jouventin, J.-P. Roux, and H. Weimerskirch. 1987. Projet d'aménagement de l'île Amsterdam. Report. Service de la Recherche (Ministerie de l'Environment), Terres Australes Antarctiques Françaises, Centre de l'etudes biologiques de Chizé, Chizé, France.

De Lisle, J. F. 1965. The climate of the Auckland Islands, Campbell Island and Macquarie Island. Proceedings of the New Zealand Ecological Society 12:37-44.

Derenne, Ph., J. L. Mougin, C. Steinberg, and J. F. Voisin. 1976. Les oiseaux de l'ile aux cochons, Archipel Crozet $\left(46^{\circ} 06^{\prime} \mathrm{S}, 50^{\circ} 14^{\prime} \mathrm{E}\right)$. Comité National Français des Recherches Antarctiques 40:107-148.

Dingwall, P. R., ed. 1995. Progress in conservation of the subantarctic islands. International Union for Conservation of Nature and Natural Resources, Gland.

Ernsting, G., W. Block, H. MacAlister, and C. Todd. 1995. The invasion of the carnivorous carabid beetle Trechisibus antarcticus on South Georgia (subAntarctic) and its effect on the endemic herbivorous beetle Hydromedion sparsutum. Oecologia (Berlin) 103:34-42.

Evenhuis, N. L. 1989. Catalogue of oceanic and Australasian Diptera. Bishop Museum Press, Honolulu; E. J. Brill, Leiden.

Frenot, Y., J. C. Gloaguen, and P. Tréhen. 1997. Climate change in Kerguelen islands and colonization of recently deglaciated areas by Poa kerguelensis and P. annua. Pages 358-366 in B. Battaglia, J. Valencia, and D. W. H. Walton, eds. Antarctic communities: species, structure and survival. Cambridge University Press, Cambridge.

Gaston, K. J. 1992. Regional numbers of insect and plant species. Functional Ecology 6:243-247.

- 1996. Species richness: measure and measurement. Pages 77-113 in K. J. Gaston, ed. Biodiversity: a biology of numbers and difference. Blackwell Science, Oxford.

Goddard Distributed Active Archive Center. 1998. Coastal zone color scanner data set. http://daac.gsfc.nasa.gov/ DATASET_DOCS/czcs_dataset.html.

Greene, S. W., and D. W. H. Walton. 1975. An annotated check list of the sub-antarctic and Antarctic vascular flora. Polar Record 17:473-484.

Greenslade, P. 1990. Notes on the biogeography of the 
free living terrestrial invertebrate fauna of Macquarie Island with an annotated checklist. Papers and Proceedings of the Royal Society of Tasmania 124:35-50.

Gremmen, N. J. M. 1981. The vegetation of the subantarctic islands Marion and Prince Edward. Junk, The Hague.

- 1997. Changes in the vegetation of sub-Antarctic Marion Island resulting from introduced vascular plants. Pages 417-423 in B. Battaglia, J. Valencia, and D. W. H Walton, eds. Antarctic communities: species, structure and survival. Cambridge University Press, Cambridge.

Gremmen, N. J. M., S. L. Chown, and D. J. Marshall. In press. Impact of the introduced grass Agrostis stolonifera on vegetation and soil fauna communities at Marion island, sub-Antarctic. Biological Conservation.

Gressitt, J. L. 1964. Insects of Campbell Island. Pacific Insects Monograph 7:1-663.

- 1970. Subantarctic entomology and biogeography. Pacific Insects Monograph 23:295-374.

- 1971. Entomology of the Aucklands and other islands south of New Zealand. Pacific Insects Monograph 27:1-340.

Hall, K. J. 1990. Quaternary glaciations in the southern ocean: sector $0^{\circ}$ long. $-180^{\circ}$ long. Quarternary Science Reviews 9:217-228.

He, F., and P. Legendre. 1996. On species-area relations. American Naturalist 148:719-737.

Higham, T. 1991. New Zealand's subantarctic islands: a guidebook. New Zealand Department of Conservation, Wellington.

Holdgate, M. W. 1960. The fauna of the mid-Atlantic islands. Proceedings of the Royal Society of London B, Biological Sciences 152:550-567.

- 1965. Part III. The fauna of the Tristan da Cunha Islands. Philosophical Transactions of the Royal Society of London B, Biological Sciences 249:361-402.

James, F. C., and C. E. McCulloch. 1990. Multivariate analysis in ecology and systematics: panacea or Pandora's box. Annual Review of Ecology and Systematics 21:129-166.

Jeannel, R. 1964. Biogéographie des terres australes de l'océan indien. Revue Française d'Entomologie 31: 319-417.

Johns, P. M. 1974. Arthropoda of the Subantarctic islands of New Zealand (1) Coleoptera: Carabidae. Southern New Zealand, Patagonian, and Falkland Islands Insular Carabidae. Journal of the Royal Society of New Zealand 4:283-302.

Jouventin, P. 1990. Shy albatrosses, Diomedea cauta salvini breeding on Penguin Island, Crozet Archipelago, Indian Ocean. Ibis 132:126.

Kennedy, A. D. 1995. Antarctic terrestrial ecosystem re- sponse to global environmental change. Annual Review of Ecology and Systematics 26:683-704.

King, J. E. 1983. Seals of the world. 2d ed. British Museum (Natural History), London; Oxford University Press, Oxford.

Kuschel, G. 1964. Insects of Campbell Island: Coleoptera: Curculionidae of the Subantarctic islands of New Zealand. Pacific Insects Monograph 7:416-493.

- 1971. Entomology of the Aucklands and other islands south of New Zealand: Coleoptera: Curculionidae. Pacific Insects Monograph 27:225-259.

- 1991. Biogeographic aspects of insularity. Atti dei Convegni Lincei 85:575-591.

Kuschel, G., and S. L. Chown. 1995. Phylogeny and systematics of the Ectemnorhinus-group of genera (Insecta: Coleoptera). Invertebrate Taxonomy 9:841-863.

Leader-Williams, N. 1988. Reindeer on South Georgia: the ecology of an introduced population. Cambridge University Press, Cambridge.

LeMasurier, W. E., and J. W. Thomson. 1990. Volcanoes of the Antarctic plate and southern oceans. Antarctic Research Series, vol. 48. American Geophysical Union, Washington D.C.

Lewis Smith, R. I. 1984. Terrestrial plant biology of the sub-Antarctic and Antarctic. Pages 61-162 in R. M. Laws, ed. Antarctic ecology. Vol. 1. Academic Press, London.

MacArthur, R. H., and E. O. Wilson. 1967. The theory of island biogeography. Princeton University Press, Princeton, N.J.

Marchand, D. 1995. Mise en reserve des terres Australes et Antarctiques Françaises protection de la flore et des invertebres autochtones. University of Rennes.

Milberg, P., and T. Tyrberg. 1993. Naive birds and noble savages - a review of man-caused prehistoric extinctions of island birds. Ecography 16:229-250.

Miskelly, C. M. 1984. Birds of the western chain, Snares Islands. Notornis 31:209-223.

Morrone, J. J., and R. S. Anderson. 1995. The Falklandius generic group: cladistic analysis with description of new taxa (Coleoptera: Curculionidae: Rhytirrhinini). American Museum Novitates no. 3121, pp. 1-14.

Pakhomov, E. A., and C. D. McQuaid. 1996. Distribution of surface zooplankton and seabirds across the southern ocean. Polar Biology 16:271-286.

Patrick, B. 1994. Antipodes Island Lepidoptera. Journal of the Royal Society of New Zealand 24:91-116.

Payne, R. W., P. W. Lane, P. G. N. Digby, S. A. Harding, P. K. Leech, G. W. Morgan, A. D. Todd, et al. 1993. GENSTAT 5 release 3 reference manual. Clarendon, Oxford.

Peck, S. B., and J. Kukalová-Peck. 1990. Origin and biogeography of the beetles (Coleoptera) of the Galápagos 
Archipelago, Ecuador. Canadian Journal of Zoology 68:1617-1638.

Prince, P. A., and J. P. Croxall. 1983. Birds of South Georgia: new records and re-evaluations of status. British Antarctic Survey Bulletin no. 59, pp. 15-27.

Rice, W. R. 1989. Analyzing tables of statistical tests. Evolution 43:223-225.

Robinson, G. S. 1984. Insects of the Falkland Islands: a checklist and bibliography. British Museum (Natural History), London.

Roff, D. A. 1990. The evolution of flightlessness in insects. Ecological Monographs 60:389-421.

Rosenzweig, M. L. 1995. Species diversity in space and time. Cambridge University Press, Cambridge.

Schulze, B. R. 1971. The climate of Marion Island. Pages 16-31 in E. M. Van Zinderen Bakker, J. M. Winterbottom, and R. A. Dyer, eds. Marion and Prince Edward Islands: report on the South African biological and geological expedition, 1965-1966. Balkema, Cape Town.

Selkirk, P. M., R. D. Seppelt, and D. R. Selkirk. 1990. Sub-antarctic Macquarie Island: environment and biology. Cambridge University Press, Cambridge.

Smith, V. R., and R. Lewis Smith. 1987. The biota and conservation status of sub-Antarctic islands. Environment International 13:95-104.

Smith, V. R., and M. Steenkamp. 1990. Climate change and its ecological implications at a subantarctic island. Oecologia (Berlin) 85:14-24.

Sokal, R. R., and F. J. Rohlf. 1995. Biometry: the principles and practice of statistics in biological research. $3 \mathrm{~d}$ ed. W. H. Freeman, New York.

Steadman, D. W. 1995. Prehistoric extinctions of Pacific island birds: biodiversity meets zooarchaeology. Science (Washington, D.C.) 267:1123-1131.

Tréhen, P., M. Bouché, P. Vernon, and Y. Frenot. 1985. Organization and dynamics of Oligochaeta and Diptera on Possession Island. Pages 606-613 in W. R. Siegfried, P. R. Condy, and R. M. Laws, eds. Antarctic nutrient cycles and food webs. Springer, Berlin.
Turbott, E. G. 1990. The checklist of the birds of New Zealand and the Ross Dependency, Antarctica. 3d ed. New Zealand Ordnance Survey, Wellington.

University of Rhode Island Graduate School of Oceanograpy. 1996. Sea surface temperature satellite image archive. http://satori.gso.uri.edu.

Wace, N. M., and M. W. Holdgate. 1976. Man and nature in the Tristan da Cunha Islands. IUCN Monograph no. 6. International Union for Conservation of Nature and Natural Resources, Gland.

Wagner, W. L., and V. A. Funk. 1995. Hawaiian biogeography: evolution on a hot spot archipelago. Smithsonian Institution Press, Washington, D.C.

Warham, J. 1996. The behaviour, population biology and physiology of the petrels. Academic Press, London.

Watson, G. E., J. P. Angle, P. C. Harper, M. A. Bridge, R. P. Schlatter, W. L. N. Tickell, J. C. Boyd, and M. M. Boyd. 1971. Birds of the antarctic and subantarctic. Antarctic Map Folio Series 14. American Geophysical Union, Washington, D.C.

Weimerskirch, H., R. Zotier, and P. Jouventin. 1989. The avifauna of the Kerguelen islands. Emu 89:15-29.

Wiencke, C., I. Bartsch, B. Bischoff, A. F. Peters, and A. M. Breeman. 1994. Temperature requirements and biogeography of Antarctic, Arctic and amphiequatorial seaweeds. Botanica Marina 37:247-259.

Williams, G. R. 1982. Species-area and similar relationships of insects and vascular plants on the southern outlying islands of New Zealand. New Zealand Journal of Ecology 5:86-96.

Woods, R. W. 1988. Guide to the birds of the Falkland Islands. Anthony Nelson, Oswestry, United Kingdom.

Young, E. C. 1995. Conservation values, research and New Zealand's responsibilities for the southern ocean islands and Antarctica. Pacific Conservation Biology 2: 99-112. 